\title{
GANDHI AND THE COW: THE ETHICS OF HUMAN/ANIMAL RELATIONSHIPS
}

\author{
MARK JUERGENSMEYER \\ University of California, Berkeley
}

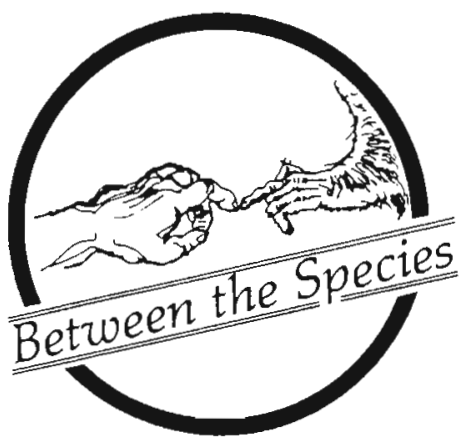

The oow is a poem of pity .. the mother to millions of Indian mankind . . Cow protection to me is one of the most wonderful phenamena in human evolution. [1]

It is a source of puzzled embarrassment to many Gandhian admirers, who otherwise find in his thoughts a happy marriage of the more sensible of Hindu concepts and the more progressive of Western values, that Gandhi was not more modest in his affection for the cow. Yet, it may also be argued, as I intend to do, that Gandhi's bovine peculiarities are integral, perhaps seminal, to the whole of his ethical stance; and that a richer understanding of the Gandhian symbol of the cow will lead to a model of human/animal ethics which may be useful in the West, where the present confusion on that issue is despaired by the supporters of animal liberation and exacerbated by the sociobiologists.

We make no claim that Gandhi's position is representative of Indian culture, for some of the more traditional reasons for venerating the cow are absent from Gandhi's approach. Despite his enigmatic claim that "the central fact of Hinduism is cow protection,"[2] Gandhi's cow is not an especially religious beast. He does not linger over Krishna's love for the cows, as characterized in the Haribamsa and the Puranas; nor does Gandhi utilize the Shaivite imagery of the scholarly and Ferdinand-like bull, Nandi. When Gandhi speaks of his "worship" of the cow, one should regard this as an almost metaphorical expression and not expect evidence of the Mahatma saying prayers and performing puja in front of cattle or ritually garlanding them with flowers.

Gandhi's veneration of the cow is also not obviously connected with caste restrictions on touching defiled and polluted matter, and eating meat. Ordinarily, In India, upper caste people do not eat meat or use leather products, in part because it would be ritually defiling to do so; whereas lower caste persons more frequently eat meat, and some have as their caste occupations the tanning and preparation of hides. Gandhi's vegetarianism was based on different notions (non-violence and nutritional, rather than ritual, purity of the body), and cow protection was not a necessary correlation to it. For a time during his wayward youth, Gandhi was a meat-eater, and later on in life he is said to have recommended eating meat to someone undernourished for lack of protein, despite the vigorous opposition of some of the upper caste residents of his Ashram at the time.[3] Gandhi also favored the expansion of tanneries, to utilize the hides of cattle which had expired through natural deaths.

\section{Economic and Political Reasons}

One may argue that instead of sacredotal and customary reasons for venerating the cow, Gandhi relies fundamentally on ethical reasons. Yet, before this argument may be made, one must acknowledge that Gandhi also had rather practical reasons for regarding the oow with some deference.

One of these practical reasons was economic. The cow is a useful and vital part of village econary, and for Gandhi, cow protection meant cow care, the maintenance of cattle as an important economic unit. Gandhi might have viewed with some sympathy the efforts of Marvin Harris to make India's teeming cattle population appear eco:lomically advisable.[4] And Gandhi might also have agreed with Alan Heston that the shabby and ill-tended cows are an economic nuisance. [5]

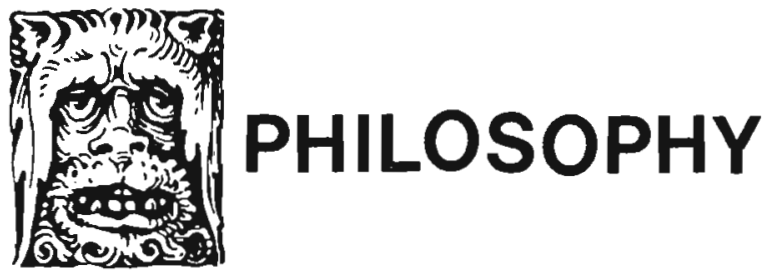


In general, Gandhi avoided the issue of whether the cow population, as presently utilized, is economically advantageous or disadvantageous. When Gandhi was presented with the argument, in 1925, by an English writer, that surplus cows cost India almost two billion rupees annually, Gandhi admitted that there might be an overall public cost to cow protection, but avowed that "a religious sentiment is not worth the name if it is not worth paying for."[6] Gandhi's solution to the problem was not to kill off the cows-which he regarded as being morally repugnant, if not impractical--but, rather, to make the existing cows econamically useful.

In fact, the bulk of Gandhi's writings about the cow are essays on the utility of modern dairy techniques, and their feasibility for India. Yet, such essays are couched in rhetoric about the sanctity of the cow. "By every act of cruelty to our cattle," Gandhi writes, "we disown God and Hinduism. . the miserable condition of our cattle." For the proper veneration of the sacred beasts, Gandhi is quick to suggest "model dairy farms and great profitable national institutions." [7]

It is clear that whatever other ethical and personal reasons Gandhi may have had for speaking kindly of the cow, it had the practical effect of stirring Hindu sympathies towards scientific dairy techniques. As he had done on many other occasions, Gandhi was arousing religious passions in a way that would effect social change, in this case, economic change.

Gandhi's interests in the cow also had political significance, especially in the context of Hindu-Muslim relations. The Muslims, after all, were the people in India most liable to slaughter cows for beef and by-products, and public sentiment among Hindus for a ban on cow slaughter has always had a double edge: the positive virtues of venerating the cow and the negative aspect of protecting the cow from its natural enemy, the Muslim butcher. It is when Hindu-Muslim tensions are at their most taut that the issue of cow protection is most visible and most visibly dangerous.

Most of Gandhi's writings about the cow were in the early $1920^{\prime} \mathrm{s}$ and in the mid-40's, two moments when Hindu-Muslin relations were critical. In the 20 's, the issue centered around the restoration of the Khilafat and the possibilities of a Hindu-Muslim alliance in Congress. In the $40^{\prime} \mathrm{s}$, it was the rise of Muslim nationalism, leading towards the creation of Pakistan, and its counterpart in militant Hinduism. In both of these instances, Gandhi's comments about cows were meant to be words of reconciliation between Hindus and Muslims. Gandhi claimed, for instance, that "it is the Hindus that do cow-selling business, and not the Musalmans," and hence Hindus are really to blame for cow-slaughter.[8] The Muslim butcher, Gandhi claimed, was simply doing his business, and it was up to the Hindu cattle merchant to make the profession economically unfeasible. Gandhi was adamantly against the legal ban on ow slaughter, for"it is obviously wrong legally to enforce one's religious practices on those who do not share that religion;"[9] rather, Gandhi urged an improvement in Hindu-Muslim relations as the only viable protection of the cow. Similar to the economic issue of scientific cow treatment, the political issue of Muslim attitudes towards cow slaughter was made publically palatable by Gandhi through an appeal to Hindu religious sentiment. It was a mark of Gandhi's ethical agility that he could take a religious notion that usually implied narrowness and prejudice, and turn it into a concept of progress and harmony.

\section{Ethical Bases for Cow Protection}

The econamic and political importance of Gandhi's cow should not, however, deter us from proceeding apace and reoognizing its ethical symbolism. There are two levels of ethical significance: the obvious linkages, which Gandhi made explicitly, and those less obvious ethical inferences which we impute to Gandhi.

Among the obvious ethical elements, the concept of ahimsa, non-violence, looms most prominent. Gandhi commonly would alternate paragraphs on cow protection with paragraphs on the concept of ahimsa, in an almost liturgical litany. There is ancient precedent for that connection, for although there does not appear to be evidence that the concept of cow protection emerged at the same time in ancient India as that of non-violence, the two concepts certainly appear to develop, buttressed by each other, during the first centuries of the Christian era. According to $\mathrm{W}$. Norman Brown, "the idea of Ahinsa and the doctrine of the sanctity of the cow slowly gain status together . . roughly about the 
What is distinctive about Gandhi's approach is that ahimsa is interpreted rather broadly, to incorporate the ethical concept of the unity of all life, and the positive injunction to love one's fellow being. According to Gandhi, "the cow merely stands as a symbol, and protection of the cow is the least [one] is expected to undertake."[11] Reverence towards the cow "takes the human being beyond his species . . . the oow to me means the entire sub-human world."[12] For Gandhi, oow reverence was a way of expanding one's consciousness, of gaining an identity with the whole of the created onder.

That wider identity is allied with the concept of mutual love, which also is reflected in the symbol of the non-violent cow. For Gandhi, non-violence means not violating the integrity of another living being. Thus, Gandhi claimed that, in his opinion, "every little breach of the ahimsa principle, like causing hurt by harsh speech to any one,man, woman or child, to cause pain to the weakest and the most insignificant creature on earth, would be a breach of the principle of oow protection . . differing from it in degree, if at all, rather than in kind."[13]

\section{Mediation Between the one and the Many}

These ethical concepts--ahinsa, respect for all life, and mutual love--are appropriate to the image of the cow, but they are somehow insufficient in explaining the distinctive power of the cow as an ethical symbol. One has the feeling that the gentle kitten, or the magnanimous water buffalo, might have done just as well. For Gandhi to have written about the oow with such virulent ethical passion, clearly same other explanations are in order. For these explanations, we will look directly at the oow itself, as Gandhi describes it, rather than relying upon Gandhi's ethical interpretations. What we have found is that the image of the cow is a symbolic mediation between two different basic ethical dilemas.

The first of those dilemmas is the dichotomy between the one and the many, the tension between the ethical primacy of the integral self and the social whole. How does the cow resolve this dilemma? On the simplest level, the cow is a resolution of the dilerma by being both one and many, the cow and many cows. Gandhi persistently uses the singular form, as Indians frequently do, in referring to the cow. And yet, of course, there are thousands of cows in India, each of whom partakes in some way in a generic sacredness. To harm any one cow is to lay a hand on the cosmic Mother.

Moreover, not just the cow itself, but one's relationship to it, is a resolution of the tension, a holistic act. The cow, after all, is a dumb animal, a thing which produces dung and pulls plows; and yet it is imputed to be also a close relative: our very mother. A thing becomes live, personable, a related extension of the self. Gandhi explains this aspect of the cow's symbolic nature as our link with all species. It is that, but it is also our link with all things, and persons whom we might otherwise regard as things, by reminding us that even the dumb cow is our symbolic mother. The otherness of the exterior world is integrated with the wholeness of the self. In Martin Buber's terms, the "it" has become a "thou."

The cow is appropriate for this symbol in part because it has been assigned that role by being designated the mother cow, the personable, self-extended, relative self. Then too, the role of the cow in the Indian village also makes this symbol appropriate, and vital. The cow is part of the family more than any other animal, physically in the center of things, its various products essential to the daily maintenance of the household, from the ghee (clarified butter) used in cooking, to the dung-cakes which are used for the cooking fires.

This image of the cow's role in the village is especially evocative for Gandhi, who thought of the Indian village as a paradigm for the harmonious community. Gandhi tended to idealize the traditional village, even though he did not live in any, except those which he recreated himself. It was in the rural pace of life, the economic selfsufficiency and direct personal relationships, that Gandhi found the closest realization of the truthful, non-violent social ideal. According to Gandhi, urban civilization has no hope until it is penetrated with "the values of the rural life."[14] The cow, then, symbolizes not only the closeness of village relationships but also the character of the village itself.

The symbol of the cow is a symbol of 
psychic unity, a mediation between individualism and differentiation, between the perils of selfishness on the one hand, and loss of self on the other. for Jung, the process of individuation accomplished that unity, by linking the singular, conscious self with the universality of the symbols of the collective unconscious. The symbol of the cow implies a similar process in Gandhian thought, but in Gandhi it also is fused with a social dimension. For as we have just seen, the cow symbolically suggests the wholeness possible in relationships with others, and the village-like harmony which is the potential of human conumities.

Mediation Between Authority and Submission

The other ethical dilemma which is symbolically resolved by the characteristics of the Gandhian cow is the tension between authority and submission, freedom and restraint. This dilemma was especially acute to Gandhi personally, for if we are to accept his autobiographical accoumt of his childhood, the tension between his father's authoritarian attitudes, and his mother's passivity was a major force in the molding of his own diverse character, and in the wars which were waged within.

In Gandhi's life history, this tension was resolved most happily in the role of nurse, a task for which Gandhi volumteered on several occasions and which he claimed gave him enormous personal satisfaction. It was in the role of nurse that Gandhi tended his father in the traumatic moments during his father's death. Nursing tasks seduced Gandhi into participating in two wars, which otherwise he likely would not have done. And there are many other instances of Gandhi playing the role of nurse-to members of his ashram, his family, calves, and miscellaneous animals.

The nursing role is an interesting resolution of the tension between authority and subrission, because it fully embodies both. The nurse is in one sense a servant, submissive and humbly waiting upan the every need of the patient. No king has been so totally tended upon as the patient in the care of an obedient and watchful nurse. And yet the patient, in his or her weakness, is totally dependent upon the nurse, and in that sense, the nurse embodies absolute and umlimited authority.
The mother-image also fits the dual roles of the nurse. Even though Gandhi viewed his own mother largely as a passive person, the image of the mother in his writings clearly indicates the power which a mother may hold, if only by reason of our dependency upon her. It is the symarome of demanding passivity, which often characterizes the mother image of modern humor: "why should you think of me, after all the sacrifices I've made for you?" The mother has enormous control, even-perhaps especiallyin her posture of self-effacement and sacrifice. Like the nurse, the mother is a mediation between authority and submission by exhibiting both of those characteristics simultaneously.

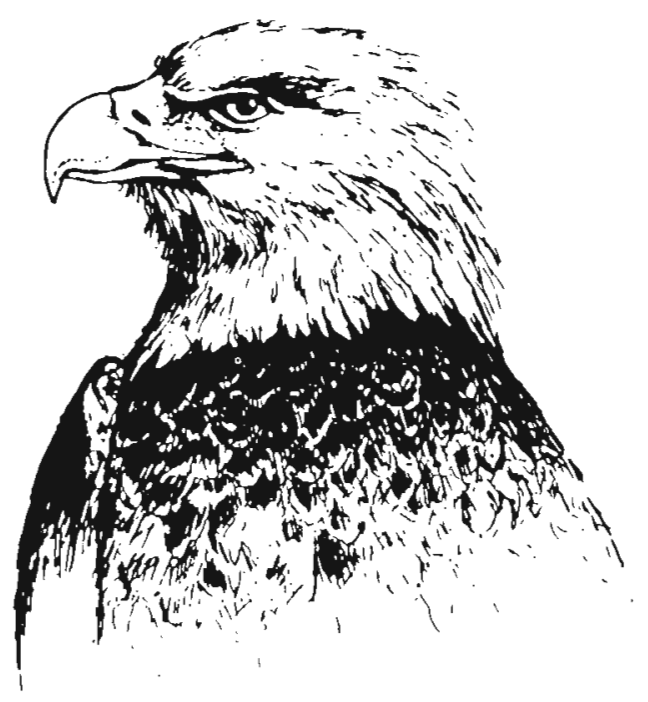

The cow, for Gandhi, is a symbol both of the passivity which characterizes the extreme of the dichotony, and, in different moods, the cow is the nurse, the mother, which resolves the duality in a passive power. The cow is sometimes offered by Gandhi as the perfect symbol of the subnissive spirit; "cow worship means to me worship of innocence. the weak and the helpless."[15] Yet this weak and helpless cow appears, in a remarkable passage written in 1940, more powerful than our biological mothers, through the sheer perfection of her sacrificial service:

Mother cow is in many ways better than the mother who gave us birth. our mother gives us milk for a couple of years and then expects us to serve her when we grow up. Mother oow expects from us nothing 
but grass and grain. our mother often falls ill and expects service from us. Mother cow rarely falls ill. Here is an unbraken record of service which does not end with her death. Our mother when she dies means expenses of burial or cremation. Mother cow is as useful dead as when she is alive. We can make use of every part of her body--her flesh, her bones, her intestines, her horns and her skin. Well, I say this not to disparage the mother who gives us birth, but in order to show you the substantial reasons for my worshipping the cow. [16]

This unusual passage was quoted in its entirety, since it indicates not only the dual characteristics of the oow symbol but also scmething of Gandhi's passionate, almost erotic, expression of it. The patently cedipal overtones, however, simply underscore the argument; for the classical Dedipal pattern is also a struggle to resolve the submission to the seductive mother and the competition with the authoritarian father. The cow is a displacement of those impulses, but also a resolution of them; the elements are united in the sensual power of the cow who cares, a sensuality which is accessible through our worship and devotion, and a power which is controllable through our caretaking of the cattle.

These aspects of the cow are personal to Gandhi, but they are not wholly solipsistic, for one may argue that the basic approach of passive resistance is made out of the same stuff. That is, passive resistance is both passive and powerful in its resistance; the strategic approach is itself, like the cow, a mediation between authority and submission, the loving mother and the angry father. The coercive and the persuasive elements of passive resistance lie uneasily together, as political observers are quick to point out; yet few would deny that they are genuinely intertwined, and the one is not simply, at least for Gandhi, a ruse to hide the other. Nor would many deny that the effect of the dual elements is something of a fusion, and that Gandhi's politics, like his cow, takes a posture which is both strong and loving, insistent and caring, a posture of concern.
The cow symbolism, as employed by Gandhi, therefore has at least three ethical elements, which may be summarized as follows:

Wholeness: the unity of all life, as expressed in the concept of ahimsa, which for Gandhi includes the absence of harmful intent.

Personhood: the mediation between the one and the many which results in the regard of others as relevant persons.

Concern: the mediation between authority and submission, which results in a passive power, expressed as concern.

These three ethical elements which are suggested by Gandhi's imagery of the cow fit well into Gandhi's larger ethical structure, and that structure is dominated by a concept too sophisticated to be symbolized by a cow, the concept of satya, the harmonious good towards which conflicts are resolved in the ethical and political process known as satyagraha. Satyagraha is possible, according to Gandhi, anly when the person performing it (the satyagrahi) regards his or her opponents with sufficient personhood to be open to the possibility of discovering truth within them, and then the satyagrahi moves towards the truth--which is characterized by wholeness-with a concern for the integrity of the opponent.

Thus, the three elements symbolized by the cow are integrated pieces within the larger pattern in Gandhi's ethical thought. Nonetheless, the three cow elements of wholeness, personhood, and concern have a certain integrity by themselves, a rudimentary statement of basic ethical attitudes. And although Gandhi did not isolate these three elements from the larger context of his ethical structure, they are by themselves helpful in solving a particular problem, the ethics of human/animal relations.

The notion of wholeness provides an ethical arena, for it implies that the whole realm of relationships among the species, and within the species, are subjects for moral reflection, and the notion of wholeness serves as a gauge of holistic harmony against which those relationships may be evaluated. The concepts of personhood and concern are the indicators of the integrity of those relationships. 
This "cow ethic" of Gandhi is sufficient to build sound attitudes of humane regard for the lesser creatures. After all, one would be unlikely to abuse an animal or to treat it ungenerously, if one regarded that animal as a person with whom one has a relationship of concern. Yet, this rather elesientary moral attitude is predicated on one's acceptance of the notion of the wholeness of all life, a notion which comes easily in the Hindu context, but less easily in the context of the West, where it is rumored that only humans have been gifted with souls.

\section{Animal Rights and Animal Liberation}

Thus, in Western philosophy and religious thought, there has been an ethical lacuna in the shape of an animal, for there has never been any clear-headedness about how animals should-or could--be ethically regarded. Western law, secular as well as moral, has simply exacerbated the problem with the insistance on the concept of rights as the principle of legal and ethical behavior. Rather than our relationship with animals, it is the nature of animals thenselves which is at issue in determining whether they are or are not the sorts of things which are deserving of fundamental rights.

The animal welfare and anti-vivisection crusades, which were particularly ardent in England in the last century, and which have recently surfaced there again, and in this country, slip into the same quandary when they insist upon "animal rights."[17] Their arguments appear to be sadly tautological: animals are the sorts of things which deserve to have rights, therefore they should have rights. The problem, of course, is that if it were so obvious to everyone that animals should have rights, they would doubtless have had them. The "animal rights" people are, therefore, not arguing out of rational principle but waging a crusade, a crusade for wider recognition of the rights-worthiness of lesser species.

The problem is that rights are assigned somewhat arbitrarily and are always subject to disagreement regarding the boundary between those beings who are worthy of rights and those who are not. In earlier generations, the issue was over slaves and women, an issue which appears to be firmly settled in their favor. Today, the issue is over the rights of the foetus and the newly born, the unconscious, the comatose, and the suicidal, and the rights of animals. On the horizon are the issues of rights to be discussed by same future generation: the rights of rocks, and whether trees have standing.[18]

Perhaps the concept of "animal liberation" might itself be liberated fram the burden of an ethic based on rights. An ethic of relationships, with its implications of responsibility and concord, might be a more useful place to begin. And for that, we might modestly employ Gandhi and his threefold ethic of the cow.

\section{A Response to the Ethic of Sociobiology}

However, even if Western ethics and philosophy have been negligent in providing an understanding about the relationship of humans with other species, Western science has not. Indeed, the theological tremor which was felt on the occasion of Darwin was an indication of the seriousness with which the biological explanation was taken. The theories of evolution contained the elements of an ethic.

Yet, it has not been until the advent of sociobiology that the implications of that ethic have become abvious. Human/animal relationships, although taken seriously, are no longer of critical issue. In sociobiology the genetic dispositions to survival traits are assumed to underlie all attitudes and activities of humans and other species, including those of their inter-relationships. At its most radical extremes, sociobiology justifies, by its competitive survival advantages, certain racist and sexist attitudes, and in that justification lies the evidence of an ethic, or at least, an anti-ethic.

The starting point of sociobiology and the starting point of Gandhi are not far apart, however; both begin with the unviolatable sense of the unity of all life and the conviction that there are common standards which we should use to gauge all species. Gandhi and sociobiology part company with their choice of standands. And yet there is an area of sociobiology's concern which might admit same of Gandhi after all, this is the paradox that survival may frequently involve cooperation as well as competition.

It is a Darwinian paradox that oumpetition, in some cases, may vitiate a species" 
survival, and cooperation enhance it. The lone aggressive ant, by biting the foot of a boar, may signal his presence and find his ambitions erased by the scxape of a toe, whereas the cooperative ant, in concert with persevering thousands, could send that boar into delirious termination. The point is that even by sociobiology's own limited point of reference, the quest for survival, there is an opening for an ethic based on cooperation, mutuality of trust, and collective obligations.

The basic cow ethic of Gandhi does not require much more than that. The virtues of wholeness, personhood, and concern in relationships can be understood and even admired in species other than our own. Whether these are attitudes that are volitional in motivation or are due to biological predisposition would surely be debated, but faced with the apparent bestialization of human values by biology, we can hardly resist the temptation to humanize the acts and attitudes of the lesser beasts.

Whether the oow ethic is indeed the ethics of the cow is not, however, a soluble or urgent issue. Issues of human/animal relations may appear to be both, although those issues which are soluble are frequently not urgent, and those which are urgent often cannot be solved. We have at least in Gandhi's understanding of the cow the elements of ethical attitudes which, if they do not lift the burdens and honor the lives of other species, will surely ennoble the lives of our own in the attempt.

\section{(৫)}

Notes

1. Young India, October 6, 1921.

2. Ibid.

3. Autobiography, Part I, chapters 6-7.

4. Marvin Harris, "India's Sacred Cow," Human Nature, February, 1978, see also his Cows, Pigs, Wars and Witches (New York: Random House, 1974).

5. Alan Heston, "An Approach to the Sacred Cow of India," Current Anthropology 12 (1971).
6. Young India, August 27, 1925.

7. Young India, October 6, 1921.

8. Young India, September 8, 1921.

9. Harijan, August 31, 1947.

10. W. Norman Brown, "India's Sanctity of the Cow," Economic and Political Weekly, p. 247.

11. Young India, November 11, 1926.

12. Young India, October 6, 1921.

13. Young India, January 29, 1925.

14. Selected Works, vol. III.

15. Young India, June 8, 1921.

16. Harigan, September 15, 1940.

17. Cf. Tom Regan and Peter Singer, Animal Rights and Human Ooligations (Englewood Cliffs: Prentice-Hall, 1976) and Peter Singer's Animal Liberation (New York: Avon Books, 1975).

18. The phrase comes from the title of a book by Christopher Stone.

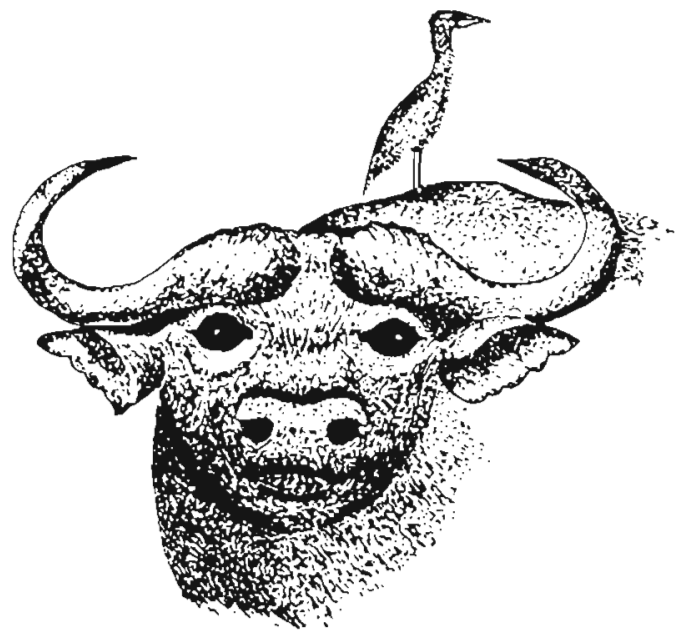

(Editor's Note: Professor Juergensmeyer has recently published a book-length study of Gandhi with Harper \& Row, entitled Fighting with Gandhi.) 